\title{
PROFESSOR EUGENIE J. A. HENDERSON: A PERSONAL NOTE
}

South-East Asia forty five years ago, with more than a hundred languages of six distinct stocks, only a handful of which had been even passably described, offered an unparalleled opportunity to linguistic inquiry. In opening up this field Eugénie Henderson, who died aged 74 on 27 July 1989, was the acknowledged leader in this country and widely respected outside it.

Her own scholarly contribution, in its versatility and range, was one which

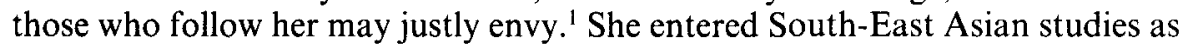
a phonetician, via wartime teaching of Japanese, and a sequence of papers c. 1950 show the originality and receptiveness to ideas that always characterized her. 'Prosodies in Siamese' of 1949 was an exemplar of Firthian method; ' The phonology of loanwords in some South-East Asian languages' of 1951 introduced the fruitful idea of irregular sub-systems pointing to borrowing; "The main features of Cambodian pronunciation' of 1952, modestly entitled and still thumbed, identified the distinctive use of voice quality found in some MonKhmer languages. Altogether, her work was to engage four of the language families of the region, though Mon-Khmer perhaps came off best. Vietnamese was one continuing interest; her magisterial paper in the J. R. Firth memorial volume of 1966 aptly returned to prosodic analysis. The arrival of a Khasi research student led to a whole series of papers on the language from 1965 onwards, with a posthumous one still to come.

Her interests were by no means restricted to phonetic and phonological topics; they embraced morphology, grammar, and some excursions into comparison both typological and genetic. She held the Chair of Phonetics in the University of London from 1964 until her retirement in 1982.

But Eugénie Henderson's personal output was only part of her contribution to her subject. Senior in the field, she was tireless in promoting and encouraging the work of others. In the late 1940s it had fallen to her to oversee the training of the post-Scarbrough recruits to the Department of South-East Asia. It was natural that in 1960 , when a vacancy arose, she should come as Acting Head to that Department; a post she held for six years, before moving on to spend a further three years (1966-69) as Head of the Department of Phonetics and Linguistics. She took as much care in bringing on the diffident as the aspiring stars. The two conferences on South-East Asian linguistics organized during her headship of that department brought together a then rather sparse international community of colleagues, and paved the way to subsequent specialist meetings around the world.

It is apt that her chosen instrument was the clavichord; an instrument where delicacy of touch and accuracy of ear are essential, and uniquely rewarded.

H. L. SHORTo

${ }^{1}$ For a bibliography of Professor Henderson's writings, and a biographical note by Professor R. H. Robins, see J. H. C. S. Davidson (ed.): South-East Asian linguistics: essays in honour of Eugénie J. A. Henderson, London, SOAS, 1989. 